\title{
AURKA Gene
}

National Cancer Institute

\section{Source}

National Cancer Institute. AURKA Gene. NCI Thesaurus. Code C24838.

This gene is involved in cell cycle regulation and cell survival. 